\title{
Multiple-site neural tube defects: embryogenesis with complete review of existing literature
}

\author{
Harsh Deora, MCh, DNB, Dwarakanath Srinivas, MCh, Dhaval Shukla, MCh, B. Indira Devi, MCh, \\ Ajit Mishra, MCh, Manish Beniwal, MCh, Narasinga Rao Kannepalli, MCh, and \\ Sampath Somanna, MCh
}

Department of Neurosurgery, National Institute of Mental Health and Neurosciences, Bangalore, Karnataka, India

\begin{abstract}
OBJECTIVE Multiple-site neural tube defects (MNTDs) are very uncommon, with the predominant number of cases being reported in developing countries. The classic theory of neural tube closure fails to explain the occurrence of these defects. Multisite closure theory, first proposed in 1995, explains most of the occurrences with a few modifications specific to a few defects. In this paper, the authors endeavor to explain all the defects, along with their genetic and embryological bases, and to review the available literature and discuss their own experience in the management of these complex cases.
\end{abstract}

METHODS The authors retrospectively reviewed the data of all the patients treated surgically for MNTDs over that past 14 years. All possible demographic data, clinical details, and radiological imaging data were reviewed. In addition, surgical parameters, complications, and status at follow-up of more than 12 months were evaluated. All previously reported cases of MNTD were analyzed, and comparisons with the present series were made.

RESULTS A total of 3 major series (including the present one) on MNTDs have been from India. A total of 57 such cases (including those of the present series) have been reported in the available literature. While previous series reported a higher incidence of spinal defects, the present series had a higher rate of cephalic defects (55\%). Among the reported cases, insertion of a ventriculoperitoneal shunt was necessary in $12(26 \%)$, and only 4 patients were operated on in 2 stages. Neurological status at presentation dictated outcome.

CONCLUSIONS MNTDs are extremely rare, and their embryogenesis is different from that of single neural tube defects. Simultaneous repair of 2 or even 3 defects is possible in a single-stage surgery. The requirement of a shunt is uncommon, and complications following surgery are rare. Folic acid supplementation may reduce the incidence of defects. https://thejns.org/doi/abs/10.3171/2019.8.FOCUS19437

KEYWORDS neural tube defect; meningocele; multiple neural tube defects; spina bifida; closure of neural tube; embryology; meningomyelocele; encephalocele

$\mathrm{M}$ ULTIPLE-SITE neural tube defects (MNTDs) are extremely rare. Most of the cases are reported from developing nations, predominantly India or African countries. The term "multiple-site neural tube defects" refers to defects reported in a single case with "normal" neural tissue in between. It needs to be differentiated from "complex" spinal defects, as these may be many different defects (up to 5 reported) but in a contiguous manner. Thus, there may be multiple lesions, but there are not multiple sites, as these have a different embryological basis. The classic single-site neural tube closure model, which describes the initiation of the closure only at the caudal and rostral ends of the neural groove, does not provide a satisfactory explanation for MNTDs in humans, and thus the multisite theory of neural tube closure emerged. ${ }^{28}$

While defects in primary neurulation are responsible for meningomyeloceles (MMCs), lipomeningomyeloceles arise from defects of secondary neurulation. An encephalocele is a malformation of the skull vault that occurs following the closure of the neural tube. However, an encephalocele is not an abnormality of primary neural tube closure but, rather, is a defect arising as a consequence of abnormal signaling from an inappropriately patterned neural tube. Here, we endeavor to provide a comprehen-

ABBREVIATIONS MMC = meningomyelocele; MNTD = multiple-site NTD; NTD = neural tube defect; VPS = ventriculoperitoneal shunting

SUBMITTED May 31, 2019. ACCEPTED August 1, 2019.

INCLUDE WHEN CITING DOI: 10.3171/2019.8.FOCUS19437. 
TABLE 1. Summary of patient characteristics

\begin{tabular}{|c|c|c|c|c|c|c|c|c|c|}
\hline $\begin{array}{l}\text { Case } \\
\text { No. }\end{array}$ & Age & Sex & Diagnosis & Preop Deficit & Surgery & $\begin{array}{l}\text { Postop } \\
\text { Deficit }\end{array}$ & $\begin{array}{l}\text { Follow-Up } \\
\quad(>1 \mathrm{yr})\end{array}$ & $\begin{array}{l}\text { Folic Acid } \\
\text { Intake }\end{array}$ & $\begin{array}{l}\text { Family } \\
\text { History }\end{array}$ \\
\hline 1 & 9 mos & $\mathrm{F}$ & Cervical \& lumbar MMCs & No & $\begin{array}{l}\text { C3 \& L3 laminectomy, } \\
\text { defect repair }\end{array}$ & $\begin{array}{l}\text { No fresh } \\
\text { deficits }\end{array}$ & No new deficits & Not taken & No \\
\hline 2 & 4 yrs & $\mathrm{F}$ & $\begin{array}{l}\text { T8-9 atretic meningolele } \\
\text { \& SCM; cervical MMC }\end{array}$ & No & $\begin{array}{l}\text { Excision of cervical } \\
\text { swelling, dorsal } \\
\text { laminectomy \& exci- } \\
\text { sion of sac \& spur }\end{array}$ & $\begin{array}{l}\text { No fresh } \\
\text { deficits }\end{array}$ & No new deficits & $\begin{array}{l}\text { Taken; } \\
\text { details } \\
\text { unknown }\end{array}$ & No \\
\hline 3 & $1 \mathrm{mo}$ & $\mathrm{F}$ & $\begin{array}{l}\text { Occipital encephalocoele, } \\
\text { lumbar meningocele }\end{array}$ & $\begin{array}{l}\text { Lower limbs grade } \\
\quad 4 / 5\end{array}$ & $\begin{array}{l}\text { Excision of both } \\
\text { MMCs }\end{array}$ & $\begin{array}{l}\text { No fresh } \\
\text { deficits }\end{array}$ & No new deficits & Not taken & No \\
\hline 4 & 2 yrs & M & $\begin{array}{l}\text { Lower thoracic \& lumbar } \\
\text { MMCs }\end{array}$ & $\begin{array}{l}\text { Lower limbs grade } \\
3 / 5 \text {, propriocep- } \\
\text { tion impaired }\end{array}$ & $\begin{array}{l}\text { Excision of both } \\
\text { MMCs }\end{array}$ & $\begin{array}{r}\text { Lower limbs } \\
\text { grade } 3 / 5\end{array}$ & $\begin{array}{l}\text { Improved to } \\
\text { grade } 4 / 5\end{array}$ & Not taken & No \\
\hline 5 & 10 mos & M & $\begin{array}{l}\text { Lumbar MMC, It parietooc- } \\
\text { cipital encephalocoele }\end{array}$ & $\begin{array}{l}\text { Delayed mile- } \\
\text { stones }\end{array}$ & $\begin{array}{l}\text { VPS \& repair of lumbar } \\
\text { MMC }\end{array}$ & - & $\begin{array}{l}\text { Shunt malfunc- } \\
\text { tion revised }\end{array}$ & Not taken & No \\
\hline 6 & 9 mos & M & $\begin{array}{l}\text { Occipital encepahlocoele } \\
\text { \& lumbar MMC }\end{array}$ & No & $\begin{array}{l}\text { VPS f/b repair of } \\
\text { defects }\end{array}$ & $\begin{array}{l}\text { No fresh } \\
\text { deficits }\end{array}$ & - & $\begin{array}{l}\text { Taken; } \\
\text { details } \\
\text { unknown }\end{array}$ & No \\
\hline 7 & 3 yrs & M & $\begin{array}{l}\text { Frontoethmoidal \& occipi- } \\
\quad \text { tal encephalocoeles }\end{array}$ & No & $\begin{array}{l}\text { Craniotomy \& ACF } \\
\text { base repair (fronto- } \\
\text { ethmoidal only) }\end{array}$ & $\begin{array}{l}\text { No fresh } \\
\text { deficits }\end{array}$ & - & $\begin{array}{l}\text { Taken; } \\
\text { details } \\
\text { unknown }\end{array}$ & No \\
\hline 8 & $1 \mathrm{yr}$ & $\mathrm{F}$ & $\begin{array}{l}\text { Occipital \& cerebellar } \\
\text { encephalocoeles }\end{array}$ & $\begin{array}{l}\text { Delayed mile- } \\
\text { stones }\end{array}$ & $\begin{array}{l}\text { Excision \& repair of } \\
\text { both }\end{array}$ & $\begin{array}{l}\text { No fresh } \\
\text { deficits }\end{array}$ & No new deficits & Not taken & No \\
\hline 9 & 9 yrs & $\mathrm{F}$ & Cervical \& lumbar MMC & No & Excision \& repair & $\begin{array}{l}\text { No fresh } \\
\text { deficits }\end{array}$ & No new deficits & Not taken & No \\
\hline
\end{tabular}

ACS = anterior cranial fossa; $\mathrm{f} / \mathrm{b}=$ followed by $\mathrm{SCM}=$ split cord malformation; $-=$ not applicable.

sive review of all such reported cases and contribute a series of 9 such cases of our own of patients treated at a tertiary center in south India during a 14-year period.

\section{Methods}

We conducted a retrospective review of all patients with neural tube defects (NTDs) who underwent surgery at our institute from January 2005 to January 2019 and collected records of MNTDs regarding patients' demographic and clinical features at presentation and during follow-up. Data were grouped in terms of age, sex, clinical evaluation findings, associated hydrocephalus, and lower-limb sensorimotor impairment along with bowel and bladder involvement. The presence of an MMC at multiple sites ( 2 or more) or its association with an encephalocele was defined as MNTDs. Radiological studies (where available) were reviewed to document the location, anatomy, and any other associated malformations. Approval of the study by the IRB at the National Institute of Mental Health and Neurosciences was obtained prior to the study.

We also conducted a review of records on PubMed and MEDLINE using the following search terms: "multiple neural tube defects," "triple neural tube defects," "double neural tube defects," and "double meningomyelocele," and all search results were tabulated after confirming that the articles conformed to the definition of MNTDs. Multiple or composite split cord malformations were not included in this review.

\section{Results}

A total of 9 such cases were found in our hospital records, and data for the same were collected. Among the 9 cases, there were 4 males and 5 females whose age at presentation ranged from 1 month to 9 years. All of these patients had double-site defects; none presented with a triple defect. All clinical and operative details are summarized in Table 1.

\section{Case 1}

A 9-month-old girl presented with cervical and lowback swellings. Physical examination revealed a $6 \times 6-$ $\mathrm{cm}$, pedunculated, transilluminant, midcervical swelling and a $10 \times 10-\mathrm{cm}$, sessile, fluctuant, lumbar swelling (Fig. 1). The patient had no deficit, and power in her upper and lower limbs was normal, as was her bladder voiding. MRI of the spine showed a cervical meningocele and a lumbar MMC with a neural placode attached to the sac wall. At surgery, the imaging findings were confirmed. She underwent C3 and L3 laminectomies and the cervical meningocele sac and lumbar MMC were repaired. The child recovered uneventfully and was doing well at the 24-month follow-up; she had no new deficits.

\section{Case 2}

A full-term 4-year-old girl presented with swelling in the nape of her neck, which was $4 \times 4 \mathrm{~cm}$, pedunculated, 


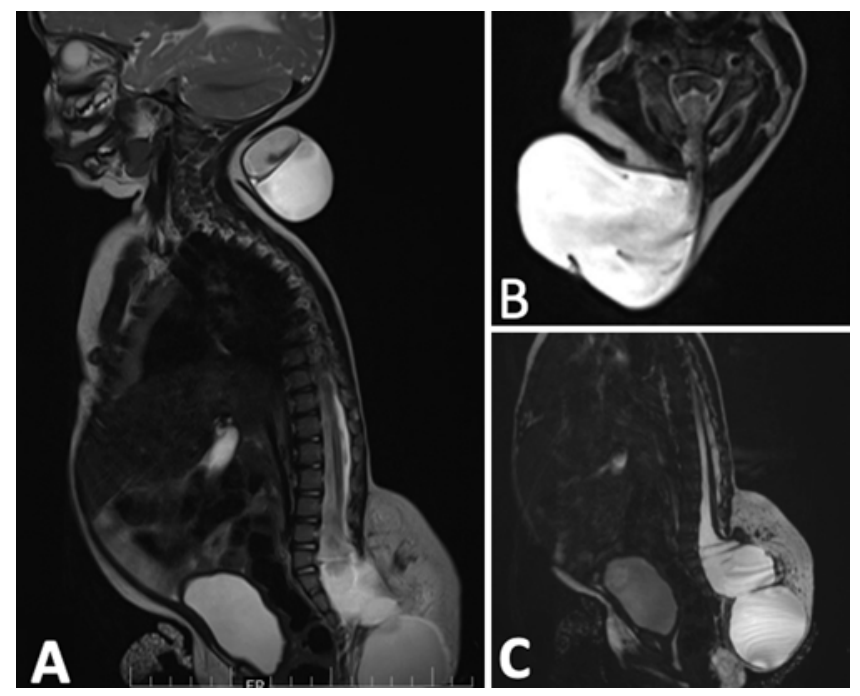

FIG. 1. Case 1. Sagittal T2-weighted MR image (A) of the spine showing a midcervical meningocele and a low lumbar MMC. Axial T2-weighted MR image of the cervical meningocele (B) and sagittal T2-weighted MR image of the lumbosacral spine showing a low lumbar MMC (C).

midcervical, and transilluminant without any deficits (Fig. 2). On further examination, there was a sessile swelling 1 $\times 1 \mathrm{~cm}$ in size at the midthoracic level with a tuft of hair over it. On MRI, there was a bony spur at that level with a type I split cord malformation. The child had no deficits and exhibited an average scholastic performance. She underwent excision and repair of the cervical MMC, with removal of the spur and then a dorsal duraplasty to place both cords in a single sac. Interestingly, the mother gave a history of taking folic acid supplements prior to delivery but periconceptional intake was not documented. The child was doing well at the 3-year follow-up.

\section{Case 3}

A full-term 1-month-old girl presented with occipital and lower lumbar swellings that she had had since birth. Her lower-limb tone was increased, and she could easily lift the lower limbs against gravity. The upper limbs were normal. There were 2 transilluminant swellings, one (2 $\times 2 \mathrm{~cm})$ in the occipital region and another $(4 \times 4 \mathrm{~cm})$ in the lower lumbar region (Fig. 3). MRI showed herniation of dysplastic cerebellar tissue in the occipital swelling and tethering of the spinal cord at the level of the lumbar MMC. At surgery, the excess sac, along with dysplastic cerebellar tissue in the occipital encephalocele, was excised and repair of the sac was performed. The MMC was explored, detethering was performed, and repair was performed. Postoperatively, her tone improved in the lower limbs. At the 14-month follow-up, her power had improved to grade $4 / 5$ in both lower limbs.

\section{Case 4}

A 2-year-old boy presented with grade $4 / 5$ weakness in both lower limbs and a 2-month history of loss of proprioception in the lower limbs bilaterally. On examination, he had 2 swellings, each $3 \times 3 \mathrm{~cm}$ in size, in the dorsal and lower lumbar levels. He underwent excision and repair of
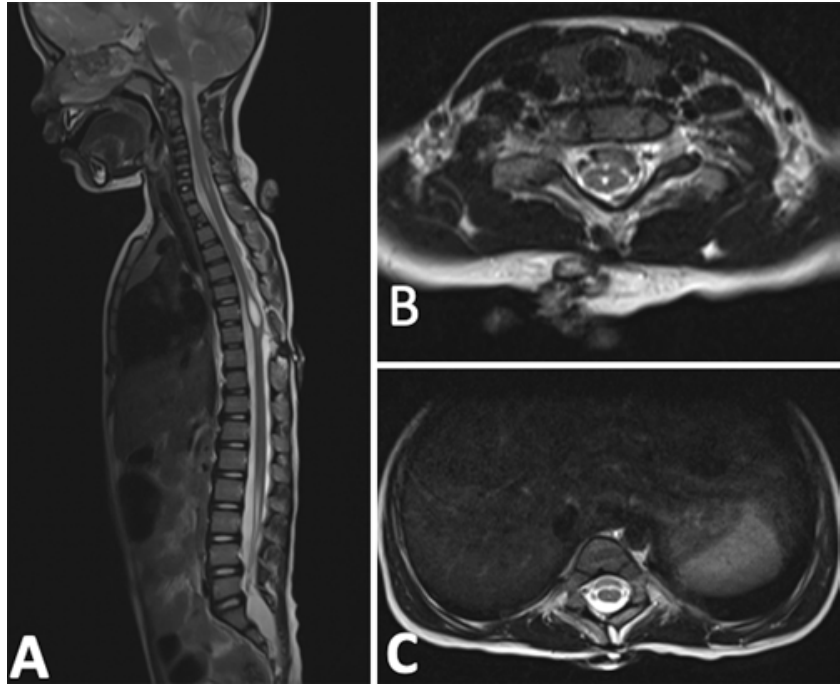

FIG. 2. Case 2. Sagittal T2-weighted MR image (A) of the whole spine showing a lower cervical MMC and a thoracic atretic meningocele at T8-9. Corresponding axial T2-weighted images ( $B$ and $\mathbf{C}$ ) of the cervical and thoracic levels showing the defects.

both defects in a single setting and in the immediate postoperative period had deterioration of strength to grade $3 / 5$, which had improved on a follow-up 15 months postoperatively to his preoperative status.

\section{Case 5}

A 10-month-old boy presented with delayed milestones and a $1 \times 1-\mathrm{cm}$ swelling in the left parietooccipital region and lower lumbar swelling, which was $4 \times 4 \mathrm{~cm}$ in size. On examination, the child had a neck holding but was unable to sit with support. MRI showed dilated ventricles with a lumbar MMC with the neural placode attached to the sac wall. He underwent ventriculoperitoneal shunting (VPS) followed by repair of the lumbar MMC defect in the same surgery. Postoperatively, the child developed a CSF leak from the lumbar site and CT scanning of the brain showed dilated ventricles. Shunt revision was done, and the child
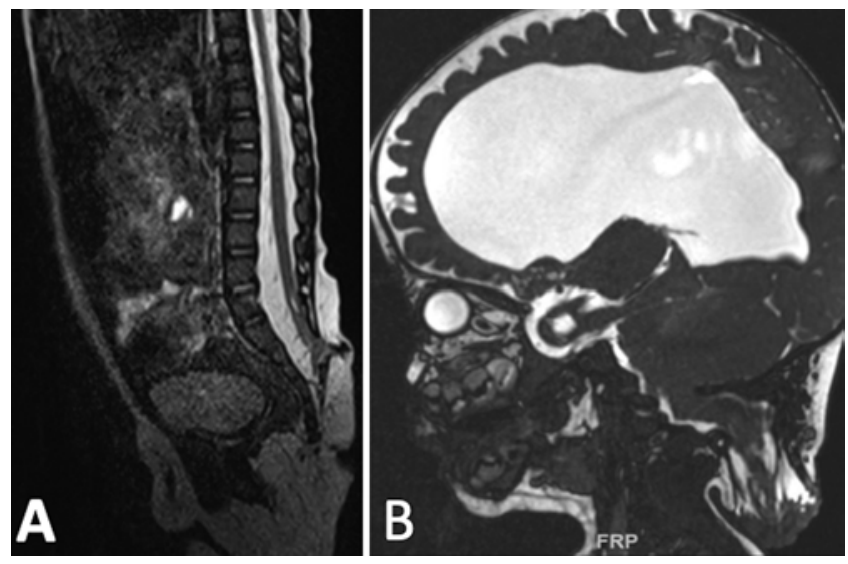

FIG. 3. Case 3. Sagittal T2-weighted MR image (A) of the lumbosacral spine showing a lumbar MMC with a tethered cord. Sagittal T2-weighted MR image (B) of the brain showing an occipital encephalocele and dilated ventricles. 


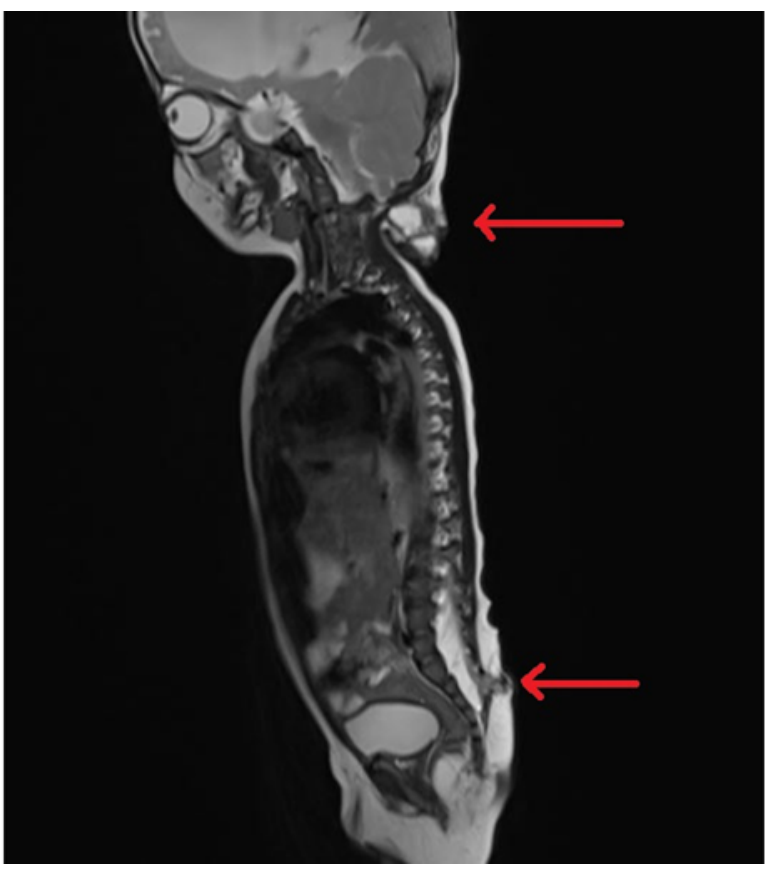

FIG. 4. Case 6. Sagittal T2-weighted MR image of the brain and spine showing dilated ventricles with herniation of the gliotic cerebellar tissue in the occipital defect and a fluid-filled sac showing a tethered neural placode at the L4-5 level (arrows).

was discharged after the lumbar wound healed. He was, however, lost to follow-up.

\section{Case 6}

A full-term 9-month-old boy presented with a tense anterior fontanelle, along with occipital and lower lumbar swellings. The occipital swelling was sessile, firm, and lobulated, measuring $2 \times 2 \mathrm{~cm}$ in size. The lumbar swelling was $3 \times 3 \mathrm{~cm}$, fluctuant, and transilluminant. MRI showed dilated ventricles with herniation of the gliotic cerebellar tissue in the occipital defect with a fluid-filled sac showing a tethered neural placode at the L4-5 level (Fig. 4). The patient underwent an emergency VPS. This was followed by repair of the occipital and lumbar defects, along with excision of the gliotic cerebellum and detethering of the cord when the patient was age 2 years. By the time of follow-up 12 months later, he was able to walk and attend playschool. A history of folic acid intake was present in the mother, but the dose and regimen that she followed were unknown.

\section{Case 7}

A full-term 3-year-old boy presented with 2 swellings that he had had since birth. One was a large, firm, lobulated swelling with a central protuberance area present in the midline nasion region (Fig. 5). Another sessile, midline $2 \times 2-\mathrm{cm}$ occipital swelling covered with healthy skin was seen (Fig. 5C). MRI of the head revealed 2 midline defects: one in the frontoethmoidal region and the other a small midline defect in the occipital bone, inferior to the larger swelling. The child was operated on for the larger frontoethmoidal defect. A bifrontal craniotomy and repair of the anterior cranial fossa base using a synthetic dural graft were performed, as was excision of the gliotic frontal tissue. The child was doing well until the follow-up at 15 months and was asked to follow up at 2 years for repair of the occipital defect but did not return. Again, a history of folic acid intake was present, but dose and regimen followed were unknown.

\section{Case 8}

A 1-year-old girl born at full term by a cesarean section presented with occipital and cerebellar swellings each $2 \times$ $2 \mathrm{~cm}$ in size (Fig. 6). She had delayed milestones: she was able to hold her neck up at 9 months and sit with support at 1 year. On imaging, the child had an occipital encephalocele and a cerebellar meningocoele. She underwent a single-stage repair of both occipital and cerebellar defects, along with gliotic tissue excision at the occipital level; a mesh cranioplasty was done to cover both defects. She has been following up for the last year and is doing well, with no evidence of hydrocephalus or a CSF leak.

\section{Case 9}

A 9-year-old girl presented with 2 atretic swellings, one $1 \times 1 \mathrm{~cm}$ at the cervical (C4) level and another measuring
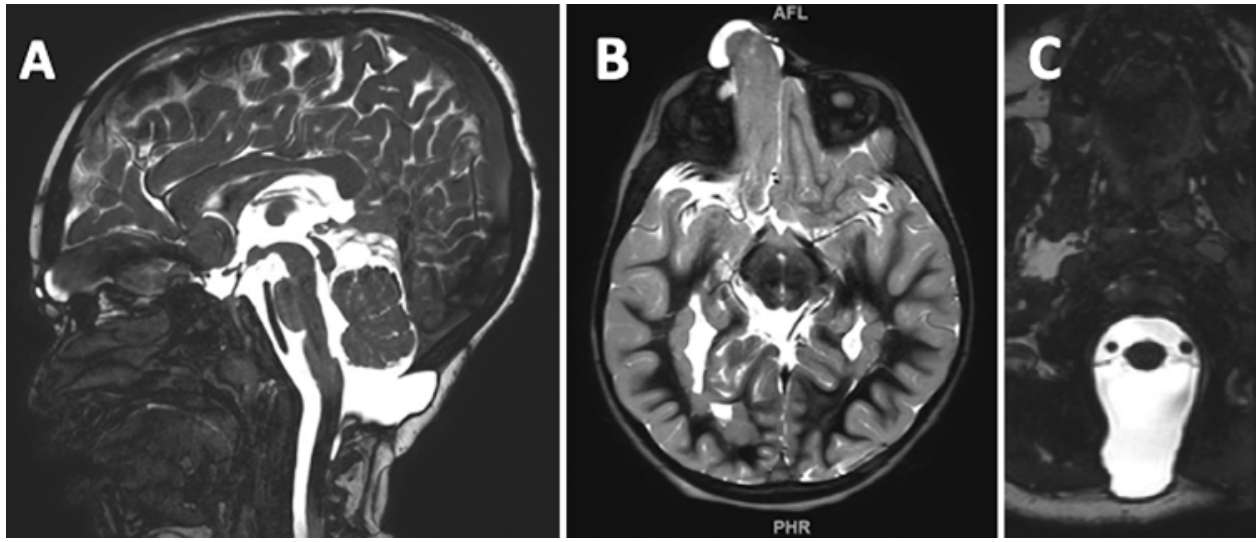

FIG. 5. Case 7. Sagittal T2-weighted MR image (A) showing frontoethmoidal and occipital encephaloceles. Axial T2-weighted MR images ( $\mathbf{B}$ and $\mathbf{C}$ ) showing the frontoethmoidal and occipital encephaloceles. 

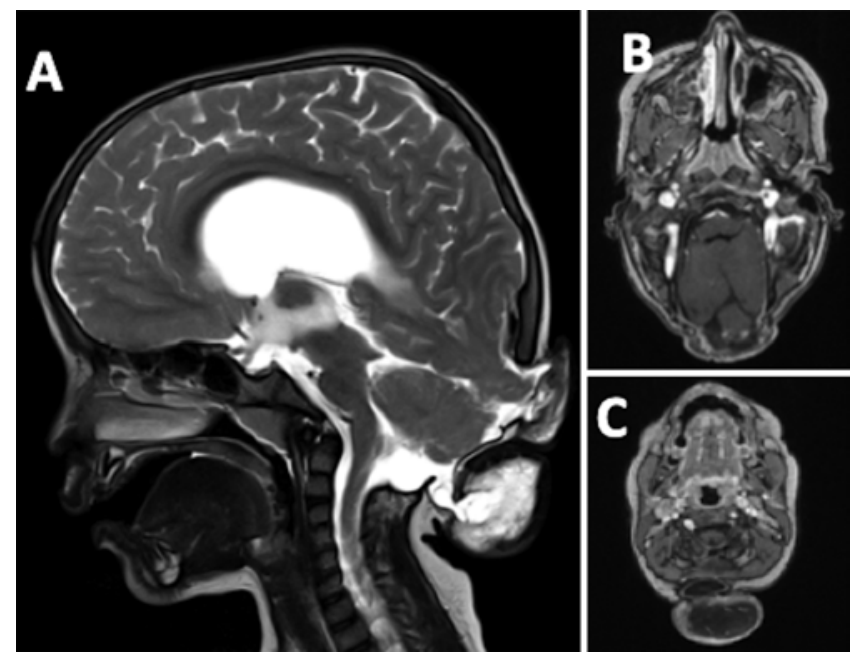

FIG. 6. Case 8. Sagittal T2-weighted MR image (A) of the brain showing 2 encephaloceles at the occiput and just below the cerebellum. Corresponding axial T1-weighted contrast-enhanced images (B and C) showing the defects.

$2 \times 3 \mathrm{~cm}$ in the lumbar spine (L4). She had no deficits and was attending school. She was concerned about the excessive growth of hair over the lower swelling. On MRI, she had MMCs at both levels, which were repaired in a single-stage surgery. She recovered uneventfully and was discharged without deficits. At a follow-up after 2 years, her wound had healed well, and she underwent laser removal of the hair regrowth.

\section{Discussion}

\section{Embryogenesis}

In 1886, von Recklinghausen proposed the nonclosure theory, and preceding this, in 1769 Morgagni proposed the overdistention theory. This latter theory could explain a majority of cases of myelomeningocele, but since then these theories have been discredited. Currently, there are two major hypotheses of neural tube closure: the deeprooted and more widely accepted theory states that the neural tube closure begins in the midcervical region. It then progresses to close the caudal and cranial neuropores (on days 24 and 26, respectively) in a zipper-like fashion both rostrally and caudally. Hence, up to S2 the neural tube forms, and caudal to it secondary neurulation takes over. This puts primary neurulation front and center in the embryogenesis of myelomeningocele. The plethora of defects reported cannot be explained by the zipper theory. According to this theory, the most caudal or the most rostral end should have been the most common site of an MMC. However, this does not explain the development of cranial NTDs. This theory also fails to explain the MNTDs, which many authors have described.

Van Allen et al. first proposed the multisite closure theory; in this, he theorized that there were 5 sites of initiation of closures, whereas closure below S2 occurs by secondary neurulation. ${ }^{28}$ The closure proceeds in an orderly fashion. Initially, it begins at site 4 followed by sites 2 and 3 and then sites 1 and 5. The senior author (D.S.) has had significant previous experience treating cases of MNTDs, ${ }^{1,23}$ and we have proposed sites of closure of the neural tube based on this theory, along with the possible defects (Table 2). However, this theory is not without its doubters. Nakatsu et al. ${ }^{13}$ studied 68 normal embryos and described 3 sites of initiation of the neural tube closure, while O'Rahilly and Müller ${ }^{14}$ could only localize 2 sites of initiation of fusion of neural folds. They concluded that closure sites 4 and 5, as referred to by Van Allen et al., do not actually exist in either mouse or human embryos. Mahalik et al. proposed that the only possible explanation for MNTDs is that the zipper process restarts even if interrupted at any site. ${ }^{12}$ This implies that the zipper restarts due to a new (rescue) initiation site. They argued that each segment of the neural tube closes independent of its adjacent segments under the stimulus of the adjacent notochordal segment. They postulated that this may be due to the interplay of Shh (Sonic hedgehog) and its antagonist, Wnt. These have been postulated as the primary mediator for initiation and sustenance of neural tube closure. Shh inhibits dorsolateral hinge point formation, and Wnt represses the Shh activity. Mahalik et al. have stated that the focal alterations in the magnitude of Shh signaling lead to focal disruption of neural tube closure, while the normal neural tube closes normally in the adjacent segments. ${ }^{12}$ Thus, each segment will have an independent potential to close. The initiation site shall merely be the segment of the neural tube that closes first. Each subsequent segment independently closes as the gradients of the pro- and

TABLE 2. Sites of closure and possible defects according to the multisite closure theory

\begin{tabular}{|c|c|c|c|c|c|}
\hline $\begin{array}{l}\text { Closure } \\
\text { Site }\end{array}$ & Site of Origin & $\begin{array}{l}\text { Direction of } \\
\text { Progress }\end{array}$ & Rostral Progression & Caudal Progression & Clinical Defect \\
\hline 1 & Midcervical level & Bidirectional & Meets site 4 & Meets site 5 & $\begin{array}{l}\text { Cervical, thoracolumbar, \& } \\
\text { lumbar MMCs }\end{array}$ \\
\hline 2 & $\begin{array}{l}\text { Junction btwn prosen- } \\
\text { cephalon \& mesen- } \\
\text { cephalon }\end{array}$ & Bidirectional & $\begin{array}{l}\text { Proceeds over prosencepha- } \\
\text { Ion \& meets site } 3\end{array}$ & $\begin{array}{l}\text { Progresses over mesencepha- } \\
\text { lon \& terminates at superior } \\
\text { part of rhombencephalon }\end{array}$ & $\begin{array}{l}\text { Frontal \& parietooccipital } \\
\text { encephalocoele }\end{array}$ \\
\hline 3 & Stomatodeum & Unidirectional & - & Meets rostral end of site 2 & Frontal encephalocoele \\
\hline 4 & Caudal rhombencephalon & Unidirectional & Meets caudal aspect of site 2 & - & $\begin{array}{l}\text { Occipital \& parietooccipital en- } \\
\text { cephalocoele, cervical MMC }\end{array}$ \\
\hline 5 & Caudal end of neural tube & Unidirectional & Meets caudal aspect of site 1 & - & Lumbosacral MMC/lipomas \\
\hline
\end{tabular}


anticlosure factors are attained chronologically with the wave of neurulation, thus leading to apparent "zippering." Any local insult to these regulatory pathways can affect the ability of succeeding segments to close, while the duration and local extent of the insult determine the extent of NTD. Once the causative insult subsides, the subsequent segments close due to their innate potential. We agree with this explanation as MNTDs can be explained by multiple local environmental insults.

Neural tube closure is also related to the segmentation of the same, which is predominantly derived from rhombomere r8. The differentiation of autonomic structures in the cord is largely responsible for regional differences. Defective molecular programming of segmentation produces multiple defects in neurulation, which also explains the Chiari type II malformation that accompanies most lumbosacral MMCs. Here the HOX gene is considered the causative agent for the hypoplasia of the basioccipital, exoccipital, and supraoccipital bones, which subsequently results in a low position of the torcula and a reduced posterior fossa volume in Chiari type II malformation. This does not happen in the cranial vault, as most of it is composed of membranous rather than endochondral bone, which is derived from the mesencephalic neural crest and is not programmed by HOX genes. ${ }^{19}$

\section{Literature Review}

Among all reported cases of MNTDs (Table 3), ${ }^{1-12,15-18 \text {, }}$ 21-27,29,30 there have been two major series reported by Ahmad et al. ${ }^{1}$ and Mahalik et al. ${ }^{12}$ While the former was a retrospective series over the course of 5 years, the latter was a prospective study that was conducted over the course of 2 years. Both of the series have been from India and along with our experience shall form the bulk of reported cases. There are certain differences that stand out. While our series is from south India, where the nutrition and folic acid supplementation are more prevalent, the Sikh population covered in the larger series was cited as the one having the highest incidence of NTDs and consequently MNTDs. Also, despite having given supplementation to the same in 3 of our cases, the children still had deficits, highlighting the need for periconceptional supplementation. A family history of NTDs was not present in any of our cases, and hence NTD can occur despite the absence of previous such births. Our study comprised a period of 14 years, with only 9 such cases of NTDs, and there was a higher rate of cranial defects with 5 (55\%) of our 9 patients having an encephalocele associated with their spinal defects, a rate higher than that seen in the two large series by Ahmad et al. $(42 \%)^{1}$ and Mahalik et al. (30\%). ${ }^{12}$ This may be due to the distribution of treatment centers in the region. While the previous two studies have been carried out at centers with no major neurosurgical centers nearby, our facility has specialized spinal care centers in the vicinity, and hence the referral pattern is probably skewed toward cranial deficits being more prevalent in our series.

We have noted varying patterns of cervical, thoracic, and lumbar defects in our experience, but no consistent combination could be discerned. Including our series, there were a total of 48 cases reported, of which only 12 required any form of shunting of the CSF. While 5 of the
17 patients reported in the previous large series refused surgery, only 1 patient did not return for follow-up surgery for a small remnant in the occipital encephalocele in our series, probably due to the absence of neurological deficits and small size of the defect. It also emphasizes the fact that surgical repair of all the defects can be attempted in a single stage. This is also exemplified in the review, as only 4 of the 45 cases needed a second surgery following CSF diversion. Furthermore, deficits at presentation dictate the outcome, as 6 of the 45 patients had muscle strength less than grade $3 / 5$ at presentation and remained the same even after surgery. Only patients with muscle strength $\geq$ grade $3 / 5$ eventually improved.

\section{The Role of Folic Acid}

Finally, there needs to be greater awareness among populations about these anomalies and the need for folic acid supplementation. Our series provides a unique opportunity to study the differences of a disease in a highincidence region and the difference that better nutritional practices can make in the incidence over the years. Despite the study duration being almost 7 times that of the largest series reported, we have approximately the equivalent number of cases. A national program that promotes fortification with folic acid may lead to a major decline in the incidence NTDs. It needs to be understood that it is not the level of folic acid or vitamin B12 in the blood that dictates the outcome. When women with affected pregnancies were tested for their serum folate and vitamin B12 levels, there were no significant differences between the two, and thus it shows that most cases are not clinically deficient in either vitamin. ${ }^{20}$ When the level of folate in red blood cells, which is a better marker of deficiency, was tested it confirmed the same finding, hence suggesting that a metabolic impairment may be present in the biochemical functions of one of these vitamins. Thus was derived the concept behind the use of folic acid to overcome this metabolic block or noncompetitive inhibition by loading the serum with folic acid. Consistent and continued efforts are needed in this direction to prevent children with these NTDs.

\section{Limitations of the Study}

Being a purely retrospective review, we cannot effectively calculate the incidence of NTDs in the region and are reliant on referral patterns. Despite our facility's being a major referral center, our series does provide a snapshot into the patterns of MNTDs. Since patients coming to the outpatient department who refused treatment could not be included, a recall bias arises that is inherent to retrospective reviews. Also, due to the long duration of records and changes in picture archiving and communication system at the hospital, many scans were lost and could not be retrieved.

\section{Conclusions}

Patients with NTDs need to be thoroughly investigated for the presence of associated neural tube anomalies. While the exact mechanism involved in the sequential closure of the neural tube is still not clear, the molecular pathways 


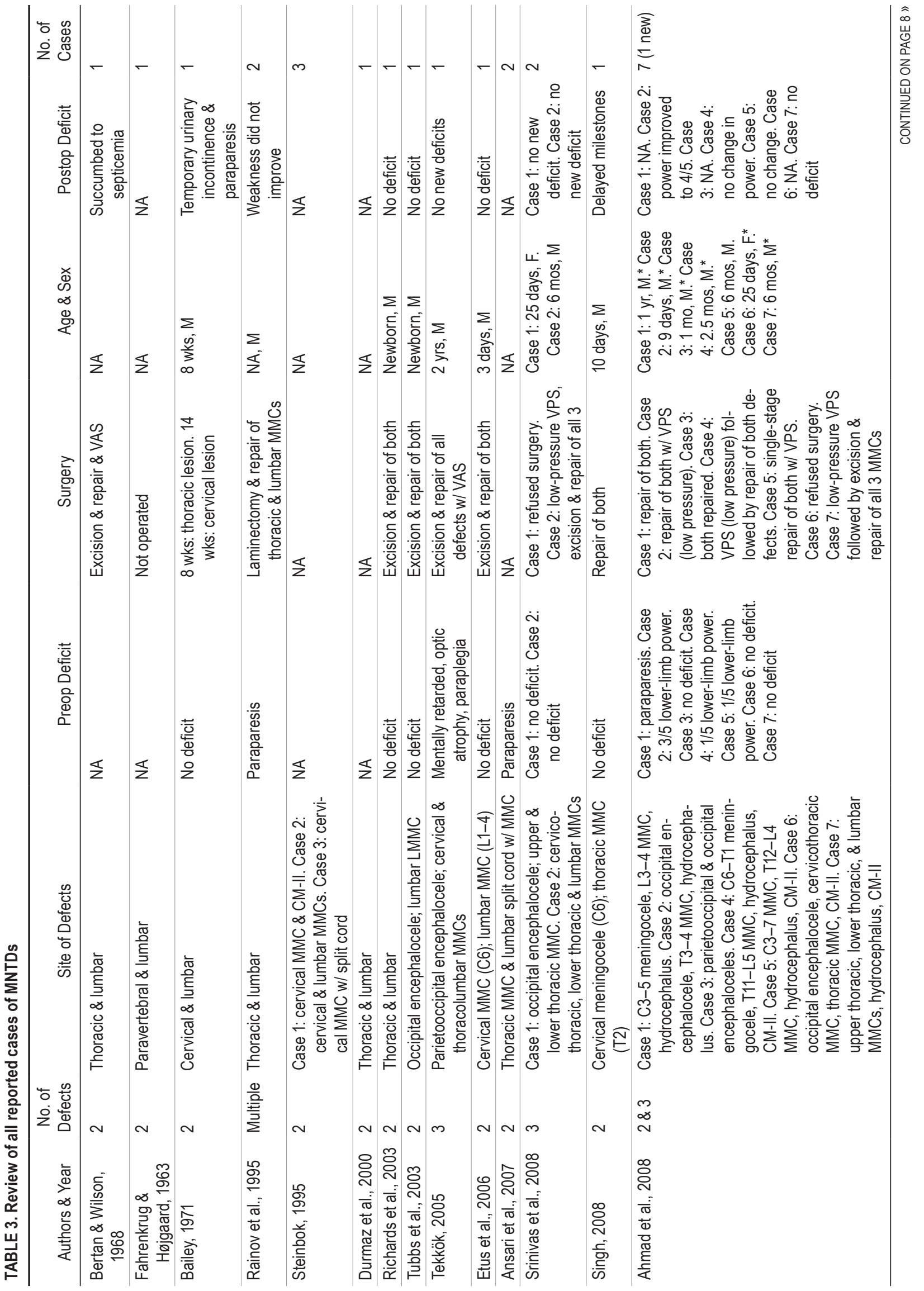




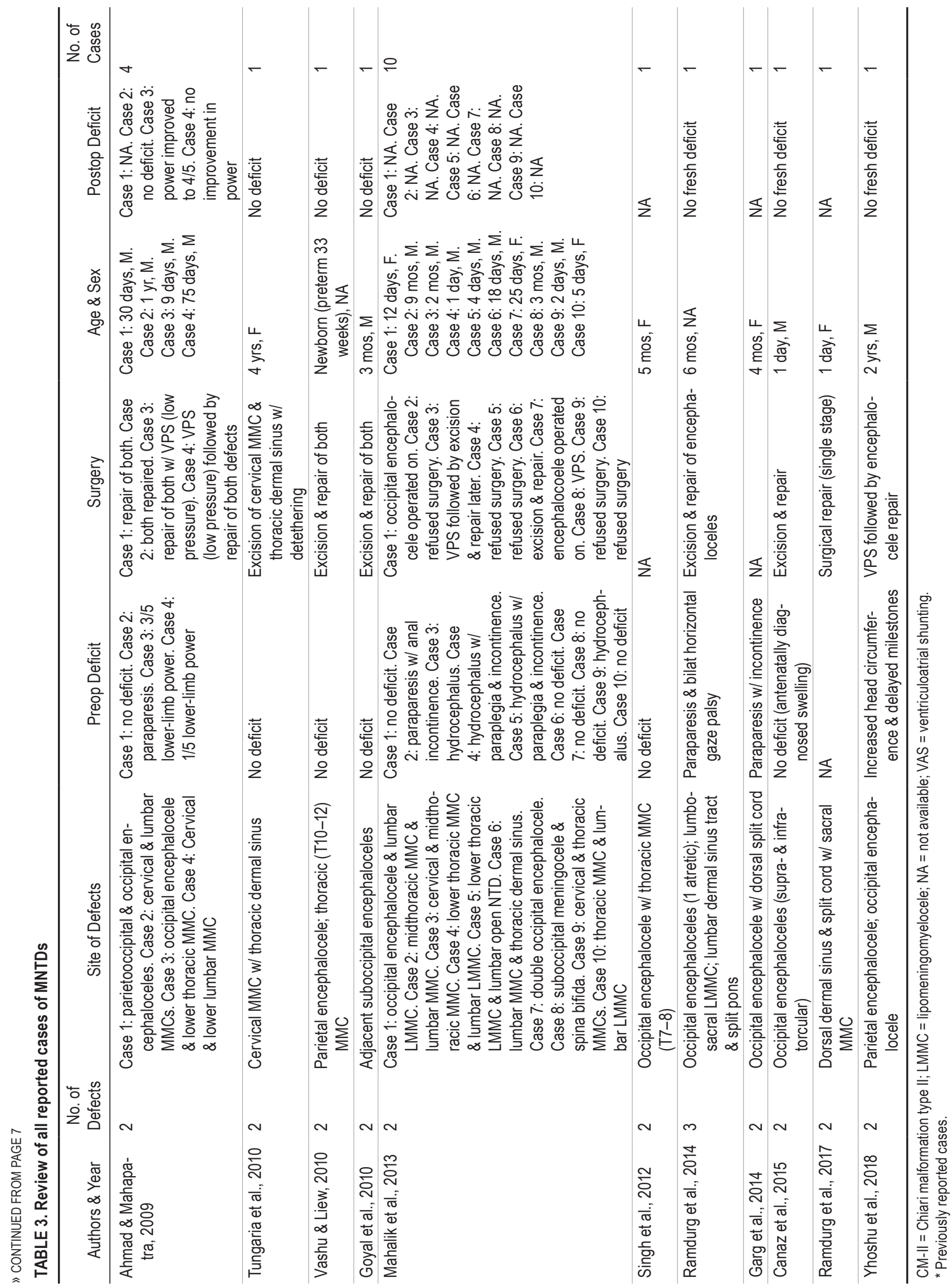


may provide us with clues as to this complex mechanism of neural tube closure. This may be the key to understanding the etiopathogenesis of MNTDs. This should be actively sought after, and folic acid, along with vitamin B12, supplementation should be the minimum possible care to overcome the metabolic block in such patients.

\section{References}

1. Ahmad FU, Dwarakanath S, Sharma BS, Mahapatra AK: Multiple neural tube defects: a clinical series of seven cases and their embryological basis. Pediatr Neurosurg 44:280 287, 2008

2. Ahmad FU, Mahapatra AK: Neural tube defects at separate sites: further evidence in support of multi-site closure of the neural tube in humans. Surg Neurol 71:353-356, 2009

3. Ansari S, Nejat F, Yazdani S, Dadmehr M: Split cord malformation associated with myelomeningocele. J Neurosurg 107 (4 Suppl):281-285, 2007

4. Bailey IC: Double meningocele. Arch Dis Child 46:549_ 550, 1971

5. Bertan V, Wilson CB: Double myelomeningocele. A case report. Turk J Pediatr 10:88-90, 1968

6. Canaz H, Ayçiçek E, Akçetin MA, Akdemir O, Alataş I, Özdemir B: Supra- and infra-torcular double occipital encephalocele. Neurocirugia (Astur) 26:43-47, 2015

7. Durmaz R, Arslantaş A, Ozön YH, Tel E: Double meningocele. Case report. Turk J Pediatr 42:331-333, 2000

8. Etus V, Ilbay K, Akansel G, Ceylan S, Ceylan S: Double myelomeningocele in a neonate: case report and review of the literature. Clin Neurol Neurosurg 108:595-600, 2006

9. Fahrenkrug A, Højgaard K: Multiple paravertebral lumbar meningocele. Br J Radiol 36:574-577, 1963

10. Garg K, Tandon V, Gupta DK, Sharma BS: Multiple neural tube defect with split cord malformation-a rare entity. Indian J Pediatr 81:982-983, 2014

11. Goyal PK, Singh D, Singh H, Tandon M: Suboccipital double barrel twin meningocoele: Another new theory? J Pediatr Neurosci 5:126-128, 2010

12. Mahalik SK, Vaze D, Kanojia RP, Narasimhan KL, Rao KLN: Multiple neural tube defects may not be very rare. Childs Nerv Syst 29:609-619, 2013

13. Nakatsu T, Uwabe C, Shiota K: Neural tube closure in humans initiates at multiple sites: evidence from human embryos and implications for the pathogenesis of neural tube defects. Anat Embryol (Berl) 201:455-466, 2000

14. O'Rahilly R, Müller F: The two sites of fusion of the neural folds and the two neuropores in the human embryo. Teratology 65:162-170, 2002

15. Rainov NG, Heidecke V, Burkert W: Thoracic and lumbar meningocele in neurofibromatosis type 1 . Report of two cases and review of the literature. Neurosurg Rev 18:127-134, 1995

16. Ramdurg SR, Gubbi S, Odugoudar A, Kadeli V: A rare case of split pons with double encephalocoele, dermal sinus tract, and lipomeningomyelocele: a case report and review of literature. Childs Nerv Syst 30:173-176, 2014

17. Ramdurg SR, Shubhi D, Vishal K: Multiple neural tube defects: a rare combination of limited dorsal myeloschisis, diplomyelia with dorsal bony spur, sacral meningocoele, syringohydromyelia, and tethered cord. Childs Nerv Syst 33:699-701, 2017
18. Richards TA, Kortesis BG, Glazier S, Argenta LC, David LR: Double myelomeningocele: case report and review. Br J Plast Surg 56:306-308, 2003

19. Sarnat HB: Disorders of segmentation of the neural tube: Chiari malformations. Handb Clin Neurol 87:89-103, 2007

20. Scott JM, Weir DG, Molloy A, McPartlin J, Daly L, Kirke P: Folic acid metabolism and mechanisms of neural tube defects. Ciba Found Symp 181:180-191, 1994

21. Singh N, Singh DK, Aga P, Singh R: Multiple neural tube defects in a child: a rare developmental anomaly. Surg Neurol Int 3:147, 2012

22. Singh P: Double meningomyelocoele: case report and anatomical rationale. J Anat Soc India 57:43-46, 2008

23. Srinivas D, Sharma BS, Mahapatra AK: Triple neural tube defect and the multisite closure theory for neural tube defects: is there an additional site? Case report. J Neurosurg Pediatr 1:160-163, 2008

24. Steinbok P: Dysraphic lesions of the cervical spinal cord. Neurosurg Clin N Am 6:367-376, 1995

25. Tekkök IH: Triple neural tube defect-cranium bifidum with rostral and caudal spina bifida-live evidence of multi-site closure of the neural tube in humans. Childs Nerv Syst 21:331-335, 2005

26. Tubbs RS, Wellons JC III, Oakes WJ: Occipital encephalocele, lipomeningomyelocele, and Chiari I malformation: case report and review of the literature. Childs Nerv Syst 19:50-53, 2003

27. Tungaria A, Srivastav AK, Mahapatra AK, Kumar R: Multiple neural tube defects in the same patient with no neurological deficit. J Pediatr Neurosci 5:52-54, 2010

28. Van Allen MI, Kalousek DK, Chernoff GF, Juriloff D, Harris M, McGillivray BC, et al: Evidence for multi-site closure of the neural tube in humans. Am J Med Genet 47:723-743, 1993

29. Vashu R, Liew NS: Double neural tube defect: a case report and discussions on neural tube development. Childs Nerv Syst 26:697-701, 2010

30. Yhoshu E, Dash V, Bawa M: Double encephalocele: an unusual presentation. J Pediatr Neurosci 13:264-266, 2018

\section{Disclosures}

The authors report no conflict of interest concerning the materials or methods used in this study or the findings specified in this paper.

\section{Author Contributions}

Conception and design: Srinivas, Deora. Acquisition of data: Srinivas, Deora, Mishra. Analysis and interpretation of data: Srinivas, Deora, Mishra. Drafting the article: Srinivas, Deora, Kannepalli. Critically revising the article: Srinivas, Deora, Kannepalli. Reviewed submitted version of manuscript: Srinivas, Shukla, Deora, Beniwal, Kannepalli. Statistical analysis: Srinivas, Deora, Shukla, Devi, Beniwal, Kannepalli. Administrative/ technical/material support: Srinivas, Deora, Shukla, Devi, Beniwal, Somanna. Study supervision: Srinivas, Deora, Beniwal, Somanna.

\section{Correspondence}

Dwarakanath Srinivas: National Institute of Mental Health and Neurosciences, Bangalore, Karnataka, India.drdwaraka@gmail. com. 